\title{
Origin of brines, salts and carbonate from shales of the Marcellus Formation: Evidence from geochemical and Sr isotope study of sequentially extracted fluids
}

Brian W. Stewart ${ }^{1 *}$, Elizabeth C. Chapman ${ }^{1 \dagger}$, Rosemary C. Capo ${ }^{1}$, Jason D. Johnson ${ }^{2}$, Joseph R. Graney $^{2}$, Carl S. Kirby ${ }^{3}$, Karl T. Schroeder ${ }^{4}$

${ }^{1}$ Department of Geology \& Planetary Science, University of Pittsburgh, Pittsburgh, PA 15260

${ }^{2}$ Department of Geological Sciences, Binghamton University, Binghamton, NY 13850

${ }^{3}$ Department of Geology, Bucknell University, Lewisburg, PA 17837

${ }^{4}$ National Energy Technology Laboratory, U.S. Department of Energy, 626 Cochrans Mill Rd., Pittsburgh, PA 15236

*Corresponding author: ph. 412-624-8883; fax 412-624-3914; bstewart@pitt.edu

$\dagger$ Current address: Echelon Applied Geoscience Consulting, 1229 Twelve Oaks Ct., Murrysville, PA 15668, USA 


\begin{abstract}
Fluids co-produced with methane from hydraulically fractured organic-rich shales of the Marcellus Formation (USA) are characterized by high total dissolved solids (TDS), including elevated levels of $\mathrm{Ba}, \mathrm{Sr}$ and $\mathrm{Br}$. To investigate the source and geologic history of these highTDS fluids and their dissolved constituents, we carried out a series of sequential extraction experiments on dry-drilled cuttings extracted within, below and above the Marcellus Shale from a well in Tioga County, New York State. The experiments were designed to extract (1) water soluble components, (2) exchangeable cations, (3) carbonate minerals, and (4) hydrochloric acidsoluble constituents. The geochemistry of the resultant leachates highlights the different geochemical reservoirs for extractable elements within the shale; notably, $\mathrm{Na}$ and $\mathrm{Br}$ were largely water-soluble, while $\mathrm{Ba}$ was extracted primarily from exchangeable sites, and $\mathrm{Ca}$ and $\mathrm{Sr}$ were found both in exchangeable sites and carbonate. Strontium isotope ratios measured on the leachates indicate that each of the element reservoirs has a distinct value. Measured ${ }^{87} \mathrm{Sr} /{ }^{86} \mathrm{Sr}$ ratios in the water soluble component are similar to those of Marcellus produced water, while the ion exchange reservoir yields lower ratios, and carbonate $\mathrm{Sr}$ is lower still, approaching Devonian-Silurian seawater values. Despite the isotopic similarity of water leachates and produced water, the total water chemistry argues against generation of produced water by interaction of hydraulic fracturing fluid with "dry" shale. The high-TDS produced water is most likely trapped formation water (within and/or adjacent to the shale) that is released by hydraulic fracturing. The formation water was affected by multiple processes, possibly including basin scale, tectonically-driven fluid flow. Significant chemical and isotopic differences between Marcellus Shale produced water and overlying Upper Devonian/Lower Mississippian produced waters suggests a hydrologic barrier has been maintained in parts of the Appalachian Basin since the late Paleozoic.
\end{abstract}




\section{Introduction}

Recent improvements in natural gas drilling and extraction techniques have led to a boom in natural gas exploration from shale units previously considered too impermeable for methane production, including the Middle Devonian Marcellus Formation in the central-eastern United States (Fig. 1). The methane in these organic-rich shales, which serve as both the source and reservoir for hydrocarbons, is accessed through a combination of hydraulic fracturing to provide permeability for gas migration, and directional drilling to maximize the fractured volume of source rock sampled at each borehole. Hydraulic fracturing involves high-pressure injection of 11 to 26 million liters of fluid (Harper, 2008; King, 2012; Maloney and Yoxtheimer, 2013) in multiple stages. The injected fluid is primarily water ( $>99 \%$ by volume; Ground Water Protection Council and ALL Consulting, 2009), but additional additives are used in different stages, including hydrochloric acid to clean cement out of the well perforations, a proppant such as quartz sand to hold open fractures created during injection, biocides, friction reducers, scale

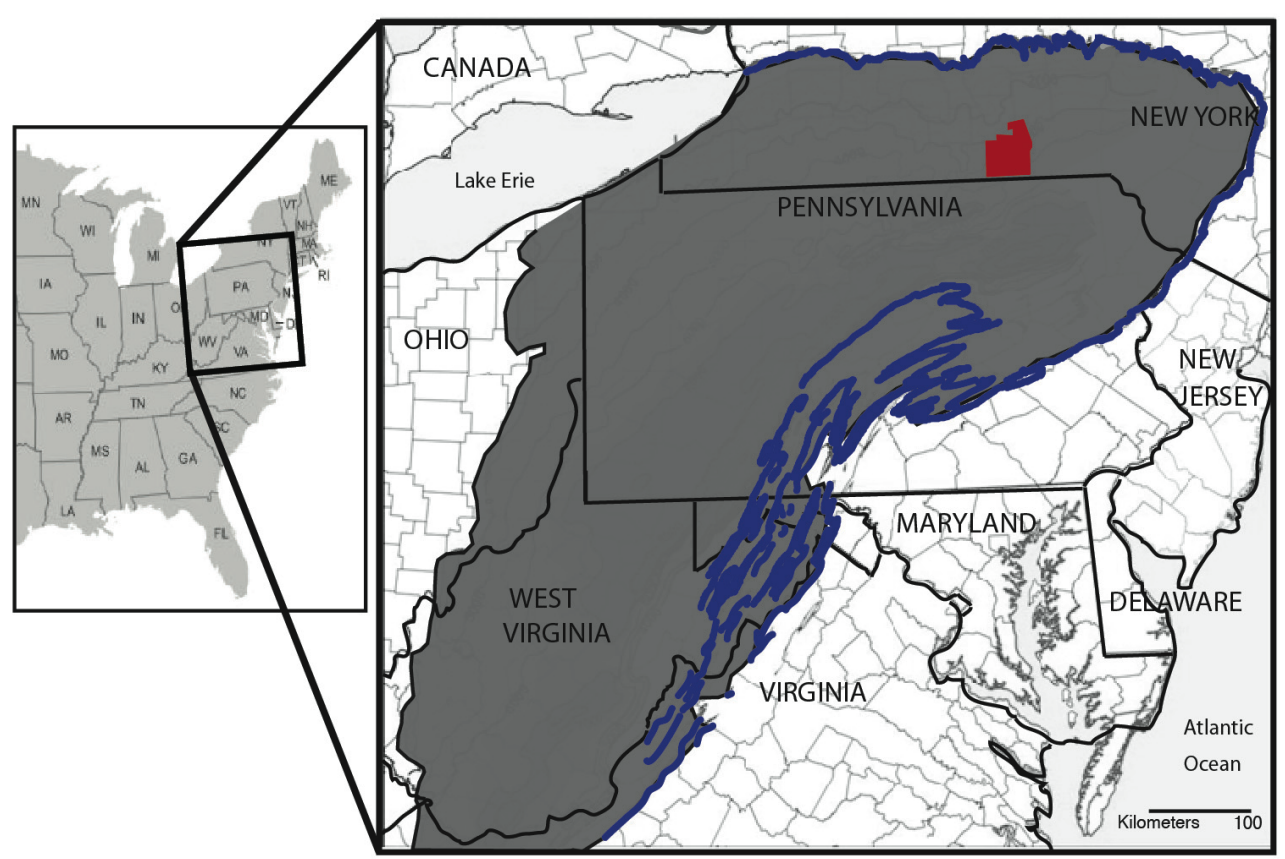

Figure 1. Map of the subsurface extent of the Marcellus Shale natural gas play (shaded) in the eastern USA. Blue lines indicate outcroppings of the shale. Tioga County, New York State, from which the cuttings for this study were obtained, is outlined in red. Modified after Milici and Swezey (2006) and Kolesar Kohl et al. (2014). 
inhibitors, corrosion inhibitors, and other components depending on the particular needs and company practice (Soeder et al., 2014).

When gas-producing shales of the Marcellus Formation (here referred to collectively as the "Marcellus Shale") are hydraulically fractured, $10-50 \%$ of the injected fluid is returned to the surface via the wellhead (Vidic et al., 2013). Most of this fluid returns in the first few days after pressure is released on the well, while smaller volumes of fluid continue to flow as methane is produced. The level of total dissolved solids (TDS) rises rapidly in the first few days of water

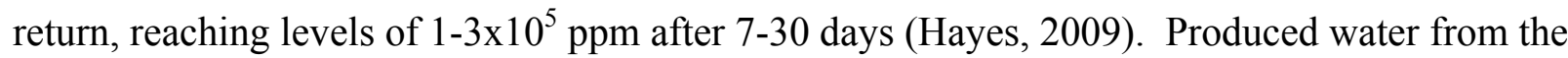
Marcellus Shale is a Na-Ca-Cl brine with high levels of $\mathrm{Sr}, \mathrm{Ba}, \mathrm{Br}$, and relatively high activities of ${ }^{226} \mathrm{Ra}$ and ${ }^{228} \mathrm{Ra}$ (Hayes, 2009; Rowan et al., 2011; Chapman et al., 2012; Haluszczak et al., 2013; Barbot et al., 2013).

The origin of the dissolved solids in the high-TDS produced water is an unresolved issue, with suggestions including dissolution of water-soluble salts in the shale formation, extraction of pore-bound water, diffusion osmosis, and accessing of formation water in shale fractures or adjacent formations (Blauch et al., 2009; Warner et al., 2012a; 2012b; Haluszczak et al., 2013; Capo et al., 2014; Engle and Rowan, 2014; Engelder et al., 2014; Balashov et al., 2015; Rowan et al., 2015). The Marcellus Formation was deposited in the Appalachian Basin, a restricted foreland basin at near-equatorial latitudes that formed in response to tectonic loading to the east (Quinlan and Beaumont, 1984; Beaumont et al., 1988; Ettensohn, 1985; 1992; 2004; Kohl et al., 2014). It overlies the Lower Devonian Onondaga Limestone, and is overlain by silts and shales of the Hamilton Group, which is capped by the Tully Limestone. The section continues upward into Upper Devonian and Lower Mississippian shales and conventional hydrocarbon-bearing sandstones. Oil and gas in these units is thought to be sourced primarily from the underlying Marcellus Shale (Milici and Swezey, 2006; Zagorski et al., 2012). The units underlying the Marcellus Formation include the hydrocarbon-bearing Ordovician Utica Shale, as well as Silurian Salina Series evaporites in the north, which transition to limestones, shales and sandstones in the south-southwestern part of the play (Carter, 2007). 
Strontium isotope studies of Marcellus Shale produced water (Chapman et al., 2012; Warner et al., 2012a; Capo et al., 2014; Kolesar Kohl et al., 2014) demonstrated that the ${ }^{87} \mathrm{Sr} /{ }^{86} \mathrm{Sr}$ ratios of waters collected over a wide region $(\sim 375 \mathrm{~km})$ fall within a relatively restricted range of values, from 0.7101 to 0.7121 . This suggests that there may be a basin-wide source for the dissolved load of the produced water. Moreover, all ${ }^{87} \mathrm{Sr} /{ }^{86} \mathrm{Sr}$ ratios for Marcellus produced water reported to date exceed those of Phanerozoic seawater, so any inferred evaporated seawater source must have been augmented by addition of a radiogenic (high ${ }^{87} \mathrm{Sr} /{ }^{86} \mathrm{Sr}$ ) component. Some studies suggest that stimulation of bacterial sulfate reduction and microbial dissolution of barite following hydraulic fracturing can vary the sulfate/alkalinity ratio (Engle and Rowan, 2014) and enhance Ba concentrations in produced water (Akob et al., 2015). Understanding the source of the co-produced fluid and its dissolved constituents can help to optimize extraction procedures, and can add constraints on some of the risks associated with shale gas extraction (Soeder et al., 2014; Vengosh et al., 2014). In addition, analysis of produced waters associated with hydraulic fracturing offers a unique opportunity to understand the origin of shale-derived fluids, and their relationship to produced water from "conventional" hydrocarbon extraction.

We report geochemical and $\mathrm{Sr}$ isotope data from a series of sequential leaching experiments carried out on drill cuttings from the Marcellus Shale and adjacent units. By selectively extracting different components of the shale (water-soluble, exchangeable, carbonate, and strong acid-soluble) we seek to understand (1) the geochemical trends exhibited by Marcellus produced water over time; (2) the origin of the high TDS levels in Marcellus produced water, and (3) the post-depositional fluid evolution history of the shale and its coexisting pore fluids and/or formation waters. 


\section{Methods}

\subsection{Samples}

Dry-drilled cuttings from a vertical well extending through the Marcellus Shale in Tioga County, NY (Fig. 1) were collected in November 2009. Each sample represents a composite of excavated material; for units above and below the Marcellus Shale, the sampling interval was 9 $\mathrm{m}$, while the sampling interval within the Marcellus Shale was $3 \mathrm{~m}$ (Johnson and Graney, 2015). For this study, we selected a subset of nine samples with median sampling depths ranging from $901 \mathrm{~m}$ to $1,434 \mathrm{~m}$ (Table 1$)$. Based on a wireline log from a nearby well ( $<5 \mathrm{~km}$ away), the

\begin{tabular}{|c|c|c|c|c|c|c|c|c|}
\hline $\begin{array}{l}\text { Sample } \\
\text { Name } \\
\end{array}$ & Unit & $\begin{array}{c}\text { Median Depth } \\
\text { (m) } \\
\end{array}$ & Quartz ${ }^{\mathrm{a}}$ & Calcite $^{\mathrm{a}}$ & Pyrite $^{a}$ & $\begin{array}{c}\text { Muscovite/ } \\
\text { Illite }^{\mathbf{a}}\end{array}$ & $\begin{array}{l}\text { Chlorite } \\
\text { Group }^{\text {a }}\end{array}$ & $\begin{array}{l}\text { \% Sample } \\
\text { Dissolved }^{\mathrm{h}} \\
\end{array}$ \\
\hline MDC-6 & Tully Limestone & 901 & $\mathrm{x}$ & $\mathrm{XX}$ & - & $\mathrm{X}$ & $\mathrm{X}$ & 60 \\
\hline MDC-22 & Hamilton Group & 1046 & $\mathrm{X}$ & - & - & $\mathrm{X}$ & $\mathrm{X}$ & 8 \\
\hline MDC-41 & Hamilton Group & 1221 & $\mathrm{X}$ & - & - & $\mathrm{X}$ & $\mathrm{X}$ & 8 \\
\hline MDC-54 & Marcellus Shale & 1337 & $\mathrm{X}$ & - & $\mathrm{X}$ & $\mathrm{X}$ & $\mathrm{X}$ & 6 \\
\hline MDC-61 & Marcellus Shale & 1358 & $\mathrm{X}$ & - & $\mathrm{X}$ & $\mathrm{X}$ & $\mathrm{X}$ & 3 \\
\hline MDC-65 & Marcellus Shale & 1370 & $\mathrm{X}$ & $X$ & $\mathrm{XX}$ & $\mathrm{X}$ & - & 14 \\
\hline MDC-71 & Marcellus Shale & 1389 & $\mathrm{X}$ & $\mathrm{XX}$ & $\mathrm{X}$ & $\mathrm{X}$ & - & 26 \\
\hline MDC-78 & Onondaga Limestone & 1410 & $\mathrm{X}$ & $\mathrm{X}$ & - & $X$ & - & 31 \\
\hline MDC-82 & Oriskany Sandstone & 1434 & $\mathrm{XX}$ & $\mathrm{XX}$ & - & $\mathrm{X}$ & - & 49 \\
\hline
\end{tabular}

inferred units from which these samples were collected are the Tully Limestone (one sample); undifferentiated Hamilton Group (two samples); organic-rich Marcellus Shale (four samples); Onondaga Limestone (one sample); and Oriskany Sandstone (one sample). The Marcellus Shale samples were readily identifiable as dark, black powders, compared to the gray color of the rest of the samples. The unit directly below the Marcellus, inferred to be the Onondaga Limestone, was markedly harder than surrounding units. None of the units encountered during drilling contained significant amounts of formation waters; the Marcellus Shale samples came up slightly damp, and were air-dried before being placed in sample vials. All samples effervesced in $8 \%$ acetic acid, indicating that some carbonate was present. 


\subsection{Sequential extraction}

A four-step aqueous sequential extraction procedure (Fig. 2) based on Stewart et al. (2001) and Spivak-Birndorf et al. (2012) was carried out on the samples as received. The procedure was designed to target different relatively accessible element reservoirs and mineral phases in the samples. The first leaching solution was water (ultrapure), added at a water:sample mass ratio of

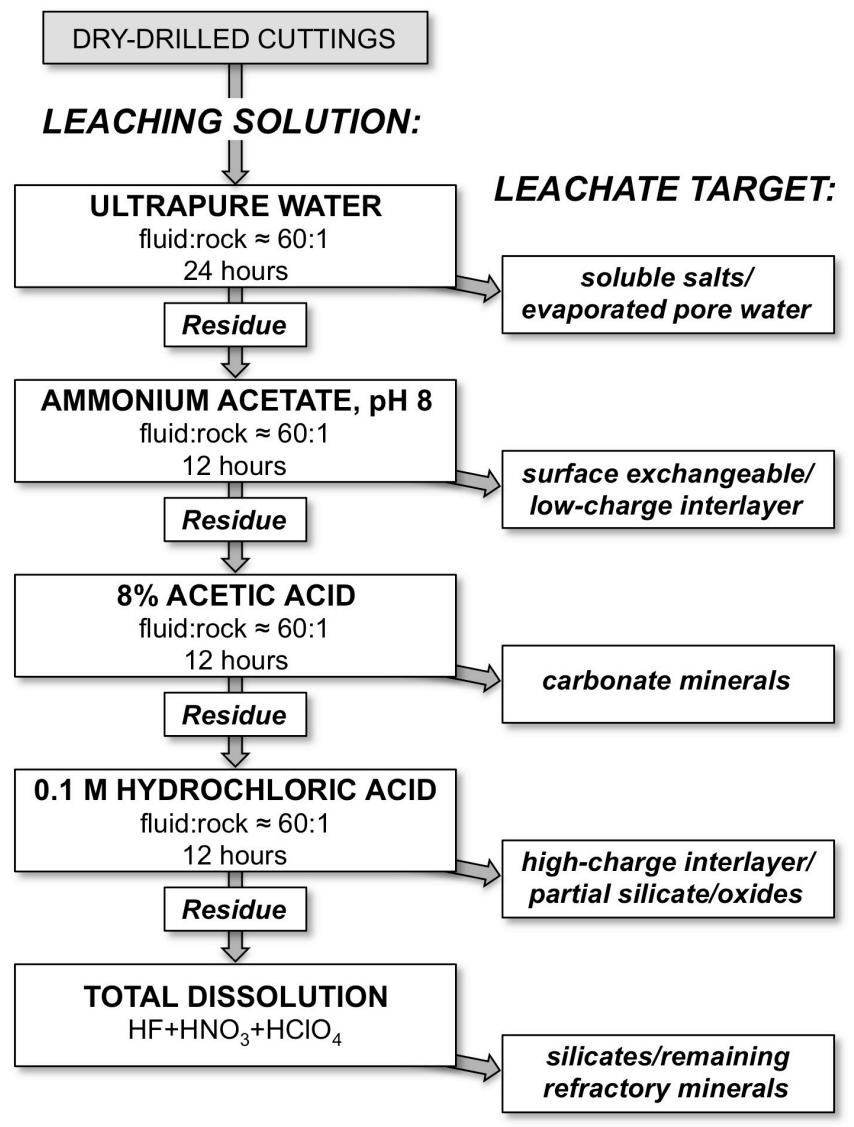

Figure 2. Flow diagram for the sequential leaching procedure used in this study. $\sim 60: 1$, to extract sample pore water and water-soluble salts, including chlorides and sulfates. The sample was shaken for 24 hours, centrifuged, and the $\mathrm{H}_{2} \mathrm{O}$ solution removed and filtered to $0.45 \mu \mathrm{m}$ for analysis. This was followed by an equal volume of ultrapure ammonium acetate $\left(\mathrm{NH}_{4} \mathrm{Ac}\right)$ buffered to $\mathrm{pH} 8$ added to the remaining sample to target exchangeable cations (displaced by the $\mathrm{NH}_{4}{ }^{+}$in the solution) at the surfaces of minerals and organic matter, as well as interlayer cations from low-charge clay structures (e.g., smectite). This procedure was carried out in a similar fashion

to the $\mathrm{H}_{2} \mathrm{O}$ leach, and was followed by equal volumes of $8 \%$ ultrapure acetic acid (HOAc)

to target carbonate minerals, and $0.1 \mathrm{M}$ ultrapure $\mathrm{HCl}$ to target acid-soluble phases. The latter treatment could extract some interlayer cations from high-charge clay structures (e.g., $\mathrm{K}$ in illite; DePaolo et al., 1983).

For the $\mathrm{H}_{2} \mathrm{O}$ leachates, an aliquot was taken and immediately refrigerated for ion chromatography analysis, and the remaining aliquot was acidified with nitric acid $\left(\mathrm{HNO}_{3}\right)$. All 
other leachate solutions were evaporated to dryness and redissolved in ultrapure $\mathrm{HNO}_{3}$ for further analysis.

After final rinsing and removal of the $\mathrm{HCl}$ leachate, the residue left in each centrifuge tube was transferred using ultrapure water into an acid-washed, preweighed PMP beaker, dried at $100^{\circ} \mathrm{C}$, and reweighed. This weight was used to calculate the total mass leached from all of the leaching solutions combined (Table 1). Two of the Marcellus Shale residues (MDC-61 and 71) were transferred to Teflon vials and dissolved completely using a combination of hydrofluoric, perchloric and nitric acids.

\subsection{Mineralogical, geochemical and isotopic analysis}

X-ray diffraction (XRD) analyses were performed at Bucknell University. To prepare the drill cuttings for analysis, a mortar and pestle were used to mill the samples to a fine powder. Samples were placed in a packed-powder mount for XRD analysis on a PANalytical X'Pert PRO MPD X-ray diffractometer with $\mathrm{Cu} \mathrm{K} \alpha$ radiation. Peak positions (d-spacings) were determined using the IdeCom software program. Search-match software was used to guide the visual inspection of XRD patterns against geologically reasonable mineral candidates in a reference library.

Leachates were analyzed for major and trace cations by ICP-MS and ICP-AES at Department of Energy's National Energy Technology Laboratory (DOE-NETL) in Pittsburgh. The water leachates were also analyzed for major anions by ion chromatography at DOE-NETL Pittsburgh.

Preparation for Sr isotope analysis was carried out under clean lab conditions at University of Pittsburgh. Aliquots containing between 0.8 and $5 \mu \mathrm{g}$ Sr were evaporated to dryness and redissolved in $6 \mathrm{~N}$ ultrapure nitric acid. Samples were then eluted through columns containing Eichrom ${ }^{\circledR}$ Sr resin in order to separate Sr from all other constituents in the sample. Column eluents were collected in acid-washed Teflon vials, evaporated to dryness, and redissolved in $2 \mathrm{~N}$ ultrapure nitric acid. For each sample, an aliquot containing 500 ng Sr was evaporated onto a rhenium filament pre-loaded with a tantalum oxide carrier agent. ${ }^{87} \mathrm{Sr} /{ }^{86} \mathrm{Sr}$ isotope ratios were 
measured using a multidynamic method on a Thermo Finnigan MAT 262 thermal ionization mass spectrometer, with an exponential mass fractionation correction to ${ }^{86} \mathrm{Sr} /{ }^{88} \mathrm{Sr}=0.1194$. The average ${ }^{87} \mathrm{Sr} /{ }^{86} \mathrm{Sr}$ ratio of SRM 987 over the period of these analyses was 0.710244 ; to facilitate comparison with other data from this lab facility, we normalized all measured ${ }^{87} \mathrm{Sr} /{ }^{86} \mathrm{Sr}$ ratios to a value for SRM 987 of 0.710240 . The estimated external reproducibility of all sample ${ }^{87} \mathrm{Sr} /{ }^{86} \mathrm{Sr}$ measurements reported here is \pm 0.000015 . Strontium isotope ratios are also reported as $\epsilon_{\mathrm{Sr}}^{\mathrm{SW}}$ (Andersson et al., 1994), defined as follows:

$$
\epsilon_{\mathrm{Sr}}^{\mathrm{SW}}=10^{4}\left[\frac{{ }^{87} \mathrm{Sr} /{ }^{86} \mathrm{Sr}_{\text {sample }}}{{ }^{87} \mathrm{Sr} /{ }^{86} \mathrm{Sr}_{\text {seawater }}}-1\right]
$$

where ${ }^{87} \mathrm{Sr} /{ }^{86} \mathrm{Sr}_{\text {seawater }}$ is the measured ratio in the present-day oceans $(0.709166$ at the University of Pittsburgh).

\section{Results}

\subsection{Mineralogy and carbonate content}

Table 1 shows the results of semi-quantitative $\mathrm{x}$-ray diffraction (XRD) analysis and postleaching mass loss. The mineralogical variations in these and additional samples from the same borehole are discussed in more detail by Johnson and Graney (2015). Quartz and illite were detected by XRD in all samples, while no halite or other water-soluble salts were detected in any of the samples. Pyrite was identified by XRD in all of the Marcellus Shale samples, but was not detected in units above and below the shale.

Most of the mass loss from the extractions (\% sample dissolved, Table 1) is expected to result from dissolution of carbonate in the acetic and hydrochloric acid extractions. The bulk of the carbonate in these samples was likely extracted by acetic acid, because it was used prior to $\mathrm{HCl}$ in the extraction procedure. To evaluate whether a significant amount of clay could have also dissolved in the HOAc, we carried out a dissolution calculation using a rate law of $5.1 \mathrm{x}$ 
$10^{-14} \mathrm{~mol} \mathrm{~m}^{-2} \mathrm{~s}^{-1}$ for illite (Köhler et al., 2003) and $5.9 \times 10^{-14} \mathrm{~mol} \mathrm{~m}^{-2} \mathrm{~s}^{-1}$ for smectite (Rozalén et al., 2008) at $\mathrm{pH}=2.4$ and $20^{\circ} \mathrm{C}$ (our experimental conditions), and an assumed BET surface area of $130 \mathrm{~m}^{2} \mathrm{~g}^{-1}$ (Köhler et al., 2003). Based on these calculations, $<0.02 \%$ of those clay minerals would dissolve during our HOAc extraction procedure.

A total of $60 \%$ of sample MDC-6 (Tully Limestone) was extracted by HOAc and HCl, while only $31 \%$ of more quartz-rich sample MDC-78 (Onondaga Limestone) dissolved, consistent with its locally siliceous character (Brett and Baird, 1996). The Oriskany Sandstone is calcareous in places and often calcite-cemented (Basan et al., 1980; Kostelnik and Carter, 2012), and calcite as well as quartz is abundant in sample MDC-82 (Table 1), which had a mass loss of 49\%. Less than $10 \%$ dissolution was observed in the two Hamilton Group samples (MDC-22 and 41) and upper two Marcellus Shale samples (MDC-54 and 61), which also contained detectable chlorite group minerals. Higher mass loss was consistent with XRD-detectable calcite in the lower two Marcellus Shale samples MDC-65 (14\%) and MDC-71 (26\%). Some variability in carbonate vs. silicate fractions could also result from the presence of small carbonate or sand lenses within the cuttings sampling interval that were incorporated into the bulk sample.

\subsection{Geochemistry of the sequential extractions}

The response of different elements to the sequential extraction solutions varies tremendously based on their geochemical affinities and the phase(s) extracted by the different solutions (Table 2). Of the cations, water-soluble, chloride-complexing cations such as $\mathrm{Na}$ are preferentially released by the $\mathrm{H}_{2} \mathrm{O}$ leach. Other alkali elements $(\mathrm{K}, \mathrm{Rb})$ are leached by water, but in some cases significant amounts are also released to ammonium acetate (from exchange sites) and $\mathrm{HCl}$ (possibly from clay interlayer sites). The alkaline earth elements ( $\mathrm{Mg}, \mathrm{Ca}, \mathrm{Sr}, \mathrm{Ba})$ also show variation in their response to the sequential leaches. Figure 3 shows the fraction of $\mathrm{Na}, \mathrm{Ca}, \mathrm{Sr}$ and $\mathrm{Ba}$ extracted from each leaching solution relative to the total amount extracted by all four leaches combined. While $\mathrm{Na}$ is almost entirely extracted by $\mathrm{H}_{2} \mathrm{O}$ (Fig. 3a), Ca is held primarily in the carbonate phase (Fig. 3b), and Sr in either exchangeable sites or carbonate (Fig. 3c), 


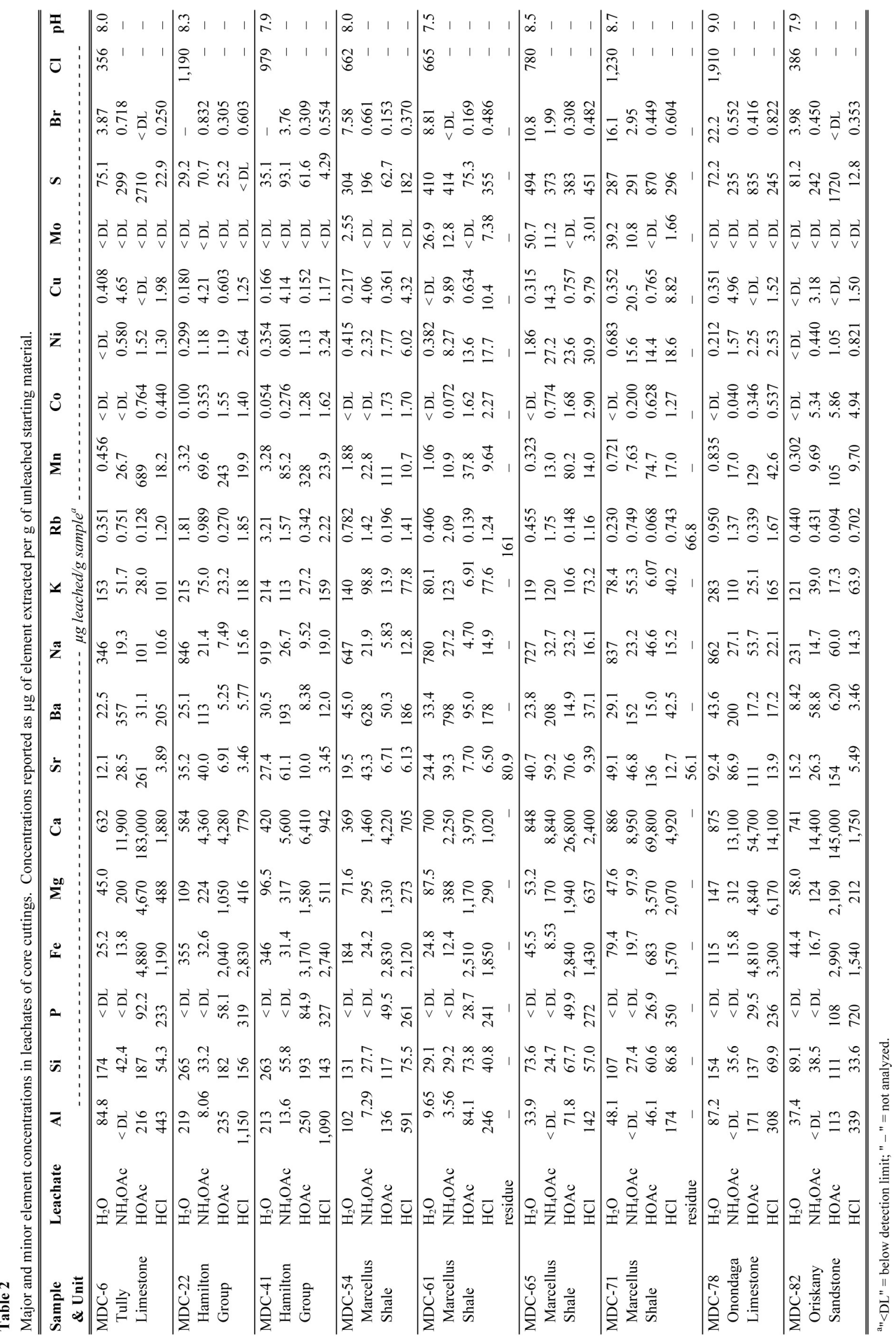


depending on the fraction of carbonate in the sample. Magnesium (not shown) behaves similarly to $\mathrm{Ca}$.

Notably, barium, which is highly concentrated in water produced from Marcellus Shale natural gas wells, is held primarily in exchangeable sites for all samples (Fig. 3d). This suggests

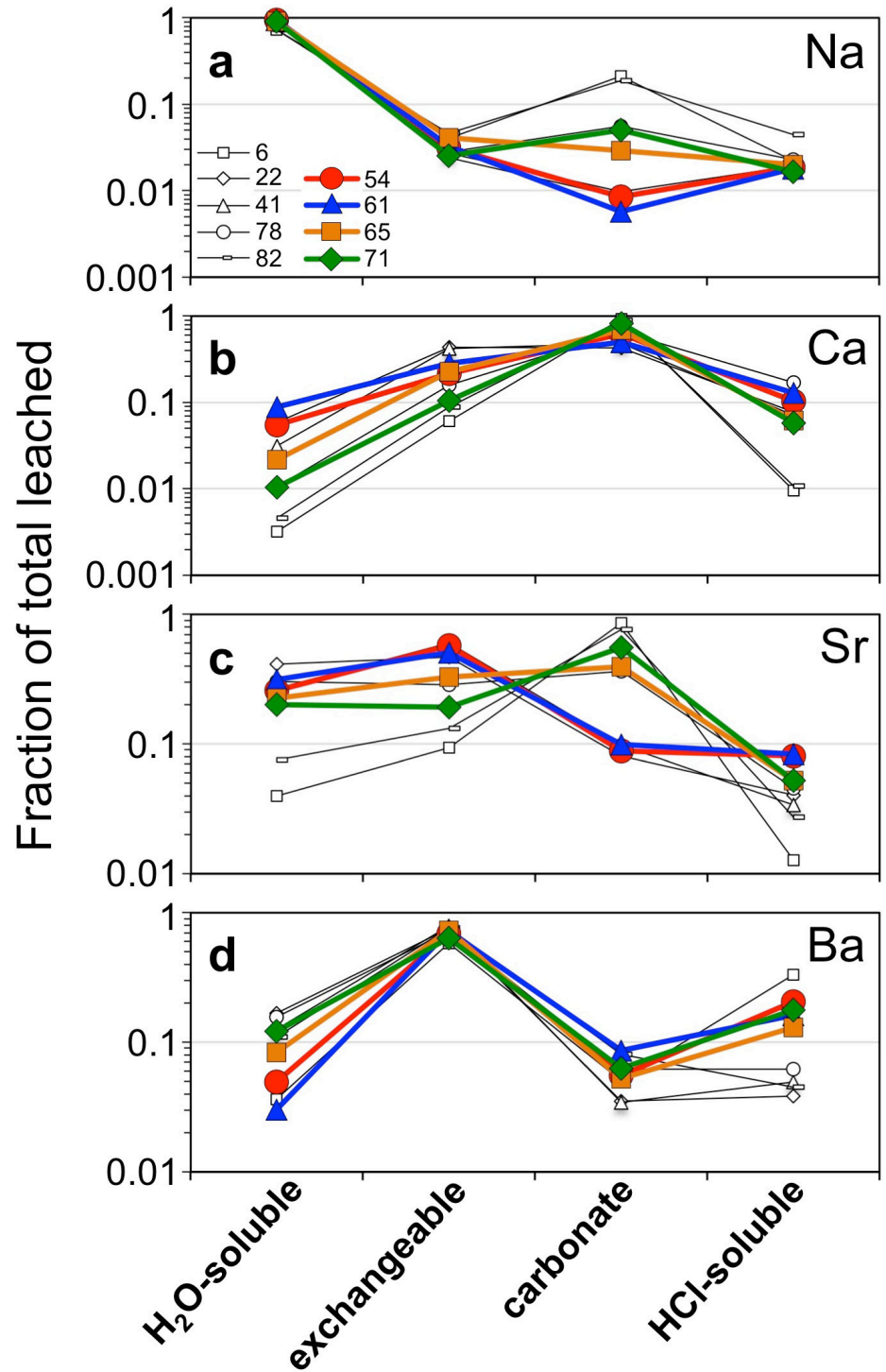

Figure 3. Fractions of $\mathrm{Na}, \mathrm{Ca}, \mathrm{Sr}$ and $\mathrm{Ba}$ leached from all samples in this study relative to the total amount extracted by the four leaching solutions. Sequential extractions took place in the order shown (left to right) that $\mathrm{Ba}$ has a strong affinity for charged surfaces on clay minerals, and that it is not held appreciably in carbonate minerals. Barite $\left(\mathrm{BaSO}_{4}\right)$, if present, was not significantly dissolved by the leaching solutions used in this study, which is consistent with its known dissolution behavior (Paytan et al., 1993).

Assuming that $\mathrm{Ca}, \mathrm{Mg}$ and $\mathrm{Fe}$ extracted by HOAc were in carbonate minerals, Ca-carbonate minerals are predominant in samples with high total carbonate content (Fig. 4), while as much as half of the carbonate in less calcareous samples is $\mathrm{Mg}$-Fe-rich, presumably in the form of dolomiteankerite, or as magnesite-siderite combined with calcite. Leachates extracted by $\mathrm{HCl}$ had higher $(\mathrm{Mg}+\mathrm{Fe}) /(\mathrm{Ca}+\mathrm{Mg}+\mathrm{Fe})$ ratios than the acetic acid fraction. This suggests dissolution by $\mathrm{HCl}$ of residual refractory $\mathrm{Fe}-\mathrm{Mg}$ carbonates and/or partial dissolution of other Mg-and Fe-rich phases such as chlorite. 


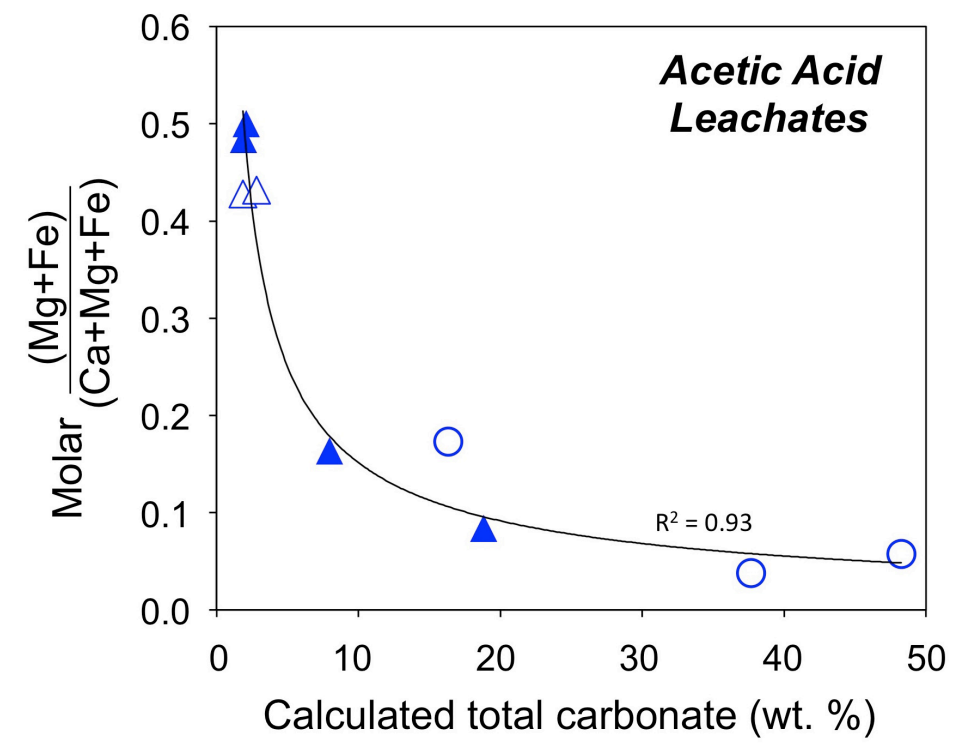

Figure 4. Molar $(\mathrm{Mg}+\mathrm{Fe}) /(\mathrm{Ca}+\mathrm{Mg}+\mathrm{Fe})$ in the acetic acid leachates for all samples in this study plotted against the calculated total weight percent carbonate content (based on acetic acid leachate chemistry). Marcellus Shale leachates are filled blue triangles, Hamilton Group leachates are open triangles, and open circles are overlying and underlying sandstones and limestones.
Phosphorus was strongly enriched in the $\mathrm{HCl}$ leachate, suggesting dissolution of a phosphate mineral such as apatite. Aluminum was extracted to the greatest extent by the $\mathrm{HCl}$ leachate in all samples, indicating partial dissolution of an aluminosilicate mineral phase. However, Si was not consistently high in the $\mathrm{HCl}$ extraction, and instead tended to peak in the $\mathrm{H}_{2} \mathrm{O}$ or HOAc extractions. Because none of the $\mathrm{pH}$ values reached levels necessary for high Si solubility ( $>9$; Krauskopf,

1956), the released silica could have been in colloidal form, possibly representing biogenic Si in the sample (Schieber, 1996).

Chloride was analyzed in the $\mathrm{H}_{2} \mathrm{O}$ leachates only, and total elemental sulfur $\left(\mathrm{S}_{\text {total }}\right)$ was determined on all samples without speciation. In the water leachates, $\mathrm{Cl}$ is present at levels roughly equivalent to $\mathrm{Na}$ (molar $\mathrm{Na} / \mathrm{Cl}$ from 0.7 to 1.8 , mean 1.3 ). Bromide, where analyzed, was highest in the $\mathrm{H}_{2} \mathrm{O}$ leachate. Sulfur showed no clear release pattern, although it tended to be enriched in the HOAc leachate fraction in samples with the highest amount of carbonate. The organic-rich shales (MDC-54, 61, 65, 71) tended to release greater amounts of S to water and ammonium acetate solutions than did other samples, probably reflecting higher amounts of pyrite. In each of these samples, however, the $\mathrm{S}_{\text {total }} / \mathrm{Fe}$ ratio in the water leachates was in excess of that of pyrite, possibly due to Fe resorption or precipitation of Fe oxyhydroxides during the leaching process; speciation modeling of the water leachates (Geochemist's Workbench ${ }^{\circledR}$ v10.1) indicates that pyrite is undersaturated and hematite and goethite are oversaturated. These conditions most likely reflect the benchtop (oxic) leaching conditions, and are not necessarily 
going to be obtained during hydraulic fracturing in the deep subsurface, where conditions are likely to be much more reducing. These models also indicate that barite is only slightly above saturation in the Marcellus Shale water leachates $\left(\mathrm{Q} / \mathrm{K}_{\mathrm{sp}}=1.2-2.6\right.$, where $\mathrm{Q}$ is the reaction quotient and $\mathrm{K}_{\mathrm{sp}}$ the solubility product constant), and suggest that Ba levels in our leaching experiments are controlled by barite solubility. Under reducing, deep subsurface conditions, it may be possible to extract greater quantities of soluble and exchangeable $\mathrm{Ba}$ from the rock, as long as sulfate levels remain low (e.g., by bacterial sulfate reduction; Engle and Rowan, 2014), suppressing barite precipitation.

\subsection{Sr isotopes in the sequential}

\section{extractions}

Measurement of isotope ratios of leachates from all samples and residues from two of the organic-rich shales (Table 3) indicate significantly different $\epsilon_{\mathrm{Sr}}^{\mathrm{SW}}$ values in different mineral and ion exchange sites within individual samples. All samples follow a trend with the sequential extractions in which the $\mathrm{H}_{2} \mathrm{O}$ leachate falls within a relatively narrow $\epsilon_{\mathrm{Sr}}^{\mathrm{SW}}$ range of +6 to $+28\left({ }^{87} \mathrm{Sr} /{ }^{86} \mathrm{Sr}=0.7096\right.$ to 0.7112$)$ that also largely overlaps with the range of Marcellus produced water values (Fig. 5), followed by a decrease in $\epsilon_{\mathrm{Sr}}^{\mathrm{SW}}$ in the $\mathrm{NH}_{4} \mathrm{Ac}$ (exchangeable) leachate, and a further decrease in the HOAc

Table 3

Strontium isotope ratios of leachates and residues

\begin{tabular}{|c|c|c|c|c|}
\hline \multirow{2}{*}{$\begin{array}{l}\text { Sample Name/ } \\
\text { Unit } \\
\text { MDC-6 }\end{array}$} & \multirow{2}{*}{$\begin{array}{l}\text { Leachate } \\
\mathrm{H}_{2} \mathrm{O}\end{array}$} & \multirow{2}{*}{$\begin{array}{c}{ }^{87} \mathbf{S r} /{ }^{86} \mathbf{S r}^{\mathrm{a}} \\
0.710852 \pm 0.000011\end{array}$} & \multicolumn{2}{|c|}{$\epsilon_{\mathrm{Sr}}^{\mathrm{s} \mathbf{w}^{\mathrm{b}}}$} \\
\hline & & & 23.77 & \pm 0.16 \\
\hline Tully & $\mathrm{NH}_{4} \mathrm{OAc}$ & $0.709868 \pm 0.000011$ & 9.90 & \pm 0.16 \\
\hline Limestone & HOAc & $0.708187 \pm 0.000010$ & -13.80 & \pm 0.14 \\
\hline MDC-22 & $\mathrm{H}_{2} \mathrm{O}$ & $0.711181 \pm 0.000010$ & 28.41 & \pm 0.14 \\
\hline Hamilton & $\mathrm{NH}_{4} \mathrm{OAc}$ & $0.710452 \pm 0.000011$ & 18.13 & \pm 0.16 \\
\hline Group & HOAc & $0.709449 \pm 0.000011$ & 3.99 & \pm 0.16 \\
\hline MDC-41 & $\mathrm{H}_{2} \mathrm{O}$ & $0.711102 \pm 0.000009$ & 27.30 & \pm 0.13 \\
\hline Hamilton & $\mathrm{NH}_{4} \mathrm{OAc}$ & $0.710449 \pm 0.000011$ & 18.09 & \pm 0.16 \\
\hline Group & HOAc & $0.709328 \pm 0.000012$ & 2.28 & \pm 0.17 \\
\hline MDC-54 & $\mathrm{H}_{2} \mathrm{O}$ & $0.710867 \pm 0.000012$ & 23.99 & \pm 0.17 \\
\hline Marcellus & $\mathrm{NH}_{4} \mathrm{OAc}$ & $0.710551 \pm 0.000010$ & 19.53 & \pm 0.14 \\
\hline \multirow[t]{2}{*}{ Shale } & HOAc & $0.709771 \pm 0.000009$ & 8.53 & \pm 0.13 \\
\hline & $\mathrm{HCl}$ & $0.711274 \pm 0.000008$ & 29.73 & \pm 0.11 \\
\hline MDC-61 & $\mathrm{H}_{2} \mathrm{O}$ & $0.710412 \pm 0.000011$ & 17.57 & \pm 0.16 \\
\hline Marcellus & $\mathrm{NH}_{4} \mathrm{OAc}$ & $0.710132 \pm 0.000010$ & 13.62 & \pm 0.14 \\
\hline \multirow[t]{3}{*}{ Shale } & HOAc & $0.709267 \pm 0.000009$ & 1.42 & \pm 0.13 \\
\hline & $\mathrm{HCl}$ & $0.710514 \pm 0.000010$ & 19.01 & \pm 0.14 \\
\hline & residue & $0.731007 \pm 0.000010$ & 307.98 & \pm 0.14 \\
\hline MDC-65 & $\mathrm{H}_{2} \mathrm{O}$ & $0.710129 \pm 0.000010$ & 13.58 & \pm 0.14 \\
\hline Marcellus & $\mathrm{NH}_{4} \mathrm{O}$ & $0.709396 \pm 0.000011$ & 3.24 & \pm 0.16 \\
\hline \multirow[t]{2}{*}{ Shale } & HOAc & $0.708276 \pm 0.000008$ & -12.55 & \pm 0.11 \\
\hline & $\mathrm{HCl}$ & $0.709833 \pm 0.000010$ & 9.41 & \pm 0.14 \\
\hline MDC-71 & $\mathrm{H}_{2} \mathrm{O}$ & $0.710126 \pm 0.000010$ & 13.54 & \pm 0.14 \\
\hline Marcellus & $\mathrm{NH}_{4} \mathrm{OAc}$ & $0.709380 \pm 0.000009$ & 3.02 & \pm 0.13 \\
\hline \multirow[t]{3}{*}{ Shale } & HOAc & $0.708248 \pm 0.000010$ & -12.94 & \pm 0.14 \\
\hline & $\mathrm{HCl}$ & $0.708915 \pm 0.000009$ & -3.54 & \pm 0.13 \\
\hline & residue & $0.731322 \pm 0.000011$ & 312.42 & \pm 0.16 \\
\hline MDC-78 & $\mathrm{H}_{2} \mathrm{O}$ & $0.709594 \pm 0.000009$ & 6.04 & \pm 0.13 \\
\hline Onondaga & $\mathrm{NH}_{4} \mathrm{OAc}$ & $0.709302 \pm 0.000011$ & 1.92 & \pm 0.16 \\
\hline \multirow[t]{2}{*}{ Limestone } & HOAc & $0.708583 \pm 0.000012$ & -8.22 & \pm 0.17 \\
\hline & $\mathrm{HCl}$ & $0.710421 \pm 0.000010$ & 17.70 & \pm 0.14 \\
\hline MDC-82 & $\mathrm{H}_{2} \mathrm{O}$ & $0.709990 \pm 0.000011$ & 11.62 & \pm 0.16 \\
\hline Oriskany & $\mathrm{NH}_{4} \mathrm{OAc}$ & $0.709418 \pm 0.000009$ & 3.55 & \pm 0.13 \\
\hline Sandstone & HOAc & $0.708766 \pm 0.000010$ & -5.64 & \pm 0.14 \\
\hline
\end{tabular}




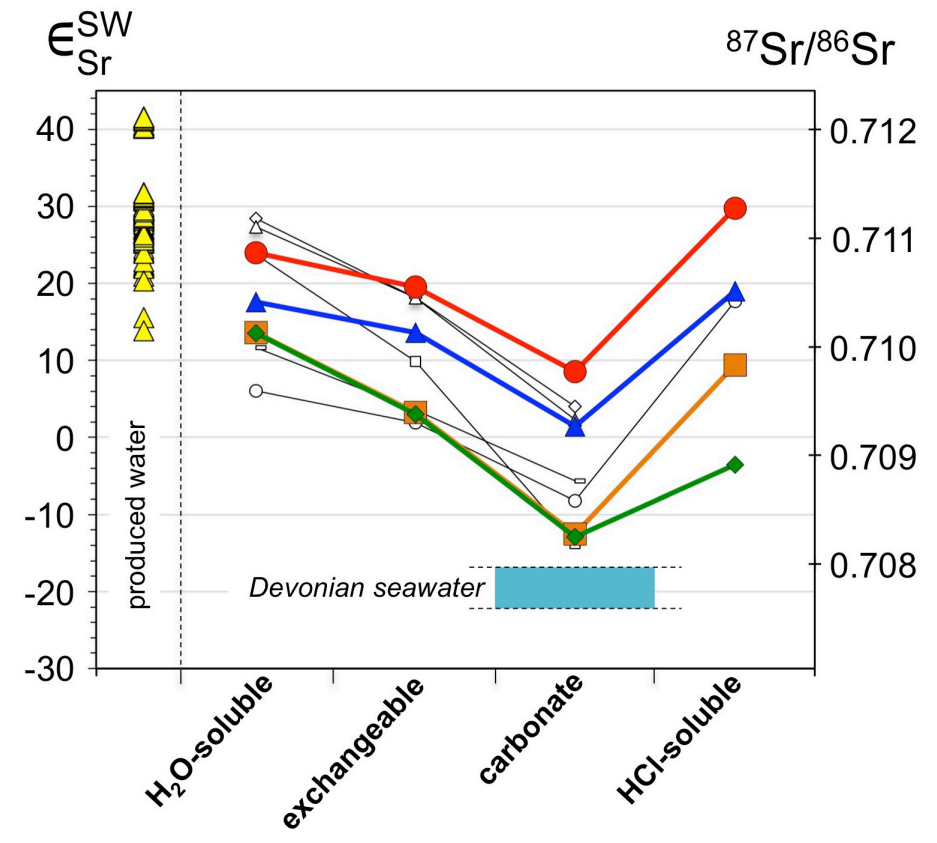

Figure 5. Strontium isotope ratio of sequential leachates of Marcellus Shale (filled symbols, colored lines) and adjacent units. Measured $\epsilon_{\mathrm{Sr}}^{\mathrm{SW}}$ values of Marcellus Shale produced water are plotted for comparison (data from Chapman et al., 2012; Capo et al., 2014). The indicated range of Devonian seawater (= unaltered Devonian marine carbonate) is from Deiner et al. (1996). Error bars on the $\epsilon_{\mathrm{Sr}}^{\mathrm{SW}}$ values are smaller than the size of the symbols. Leachate symbols are the same as in Figure 3. (carbonate) leachate, and finally an increase in $\epsilon_{\mathrm{Sr}}^{\mathrm{SW}}$ with the $\mathrm{HCl}$ leach. In the two shale samples in which the residual solid was completely dissolved and analyzed, the residue yields $\epsilon_{\mathrm{Sr}}^{\mathrm{SW}}$ values significantly higher than any of the leachates $(+308$ and +312 for MDC61 and 71, respectively). Recombining the leachate $\mathrm{Sr}$ concentrations and isotope compositions to calculate a whole-rock $\epsilon_{\mathrm{Sr}}^{\mathrm{SW}}$ value yields +164 and $+55\left({ }^{87} \mathrm{Sr} /{ }^{86} \mathrm{Sr}=0.7208\right.$ and 0.7131$)$ for MDC-61 and 71, respectively. The lower value for MCD-71 reflects the greater amount of low- $\epsilon_{\mathrm{Sr}}^{\mathrm{SW}}$ carbonate in that sample.

The low $\epsilon_{\mathrm{Sr}}^{\mathrm{SW}}$ of the carbonate fraction may provide an explanation for the trend of increasing $\epsilon_{\mathrm{Sr}}^{\mathrm{SW}}$ commonly observed during the first few days of flowback (Chapman et al., 2012; Capo et al., 2014). The earliest injected hydraulic fracturing fluid contains $\mathrm{HCl}$ to clean well perforations and improve permeability (Vidic et al., 2013). This acidic water is likely to dissolve carbonate cement and small limestone lenses within the shale, as well as portions of the well casing, lowering its $\epsilon_{\mathrm{Sr}}^{\mathrm{SW}}$ until the acid is neutralized. Based on time series analysis (Chapman et al., 2012; Capo et al., 2014), this low- $\epsilon_{\mathrm{Sr}}^{\mathrm{SW}}$ component is replaced within the first 3-10 days of flowback by Sr from preexisting formation fluids within the shale or adjacent units that are accessed through hydraulic fracturing. This is consistent with data from multiple Marcellus Shale wells reported by Hayes (2009), which showed that total alkalinity generally decreased in flowback and produced water from day 1 to day 90. Thus the mixing relationship for $\mathrm{Sr}$ 
observed between early and late returned fluids from hydraulically fractured Marcellus Shale wells (Capo et al., 2014) represents mixing between early fluids with dissolved carbonate and preexisting brines within or near the target formation.

\section{Discussion}

\subsection{Comparison of shale leachates to produced water}

An important issue for understanding and controlling produced water characteristics is the origin of the high TDS levels commonly observed in flowback just hours to days after hydraulic fracturing. Blauch et al. (2009) suggested that they result from dissolution of salt minerals in the shale by the injected fluid, while others have argued that the high TDS represent leakage of formation water back into the well via hydraulic fractures (e.g., Warner et al., 2012a; 2012b; Capo et al., 2014; Rowan et al., 2015), or extraction of pore fluids (Balashov et al., 2015). One approach is to examine the chemistry of shale leachates to determine whether available cations in soluble minerals and on surface sites can reproduce the observed chemistry (concentrations and element ratios) of produced waters. Although hydrochloric acid is added to the injected fluid during the initial stages of hydraulic fracturing (see discussion in Section 3.3, above), the acid appears to be neutralized early on, based on the $\mathrm{pH}$ of the earliest returned water (Hayes, 2009), and subsequent stages are carried out without added $\mathrm{HCl}$ (FracFocus, 2014). Therefore, for the bulk of the hydraulic fracturing process, the water leachate can be considered a reasonable approximation of hydraulic fracturing fluid interacting with shale. As indicated in Figure 6a, all of the water leachates have a higher $\mathrm{Na} / \mathrm{Cl}$ and $\mathrm{Ca} / \mathrm{Na}$ than the Marcellus produced waters. In addition, they contain a higher proportion of $\mathrm{K}$ than the produced waters, possibly from interaction with illite (Fig. 6b). 
Largely conservative behavior would expected from $\mathrm{Na}, \mathrm{Ca}$ and $\mathrm{Sr}$ in the aqueous environment as long as carbonate, sulfate or chloride salts are not precipitating. Therefore, ratios of these elements can be used to compare the leachates to produced waters. In produced waters from the Marcellus (Chapman et al., 2012; Haluszczak et al., Capo et al., 2014; Kolesar Kohl et al., 2014), both $\mathrm{Na} / \mathrm{Ca}$ and $\mathrm{Sr} / \mathrm{Ca}$ are significantly higher, in some cases by than an order of magnitude, than in any leachates from this study, including water, ammonium acetate, acetic acid, hydrochloric acid (Fig. 7a, b). In contrast, $\mathrm{Ba} / \mathrm{Ca}$ ratios in produced waters 7c) show a large variation that overlaps those of the $\mathrm{H}_{2} \mathrm{O}$ and $\mathrm{NH}_{4} \mathrm{Ac}$ shale leachates. However, $\mathrm{Ba}$ is known to vary significantly in Marcellus produced
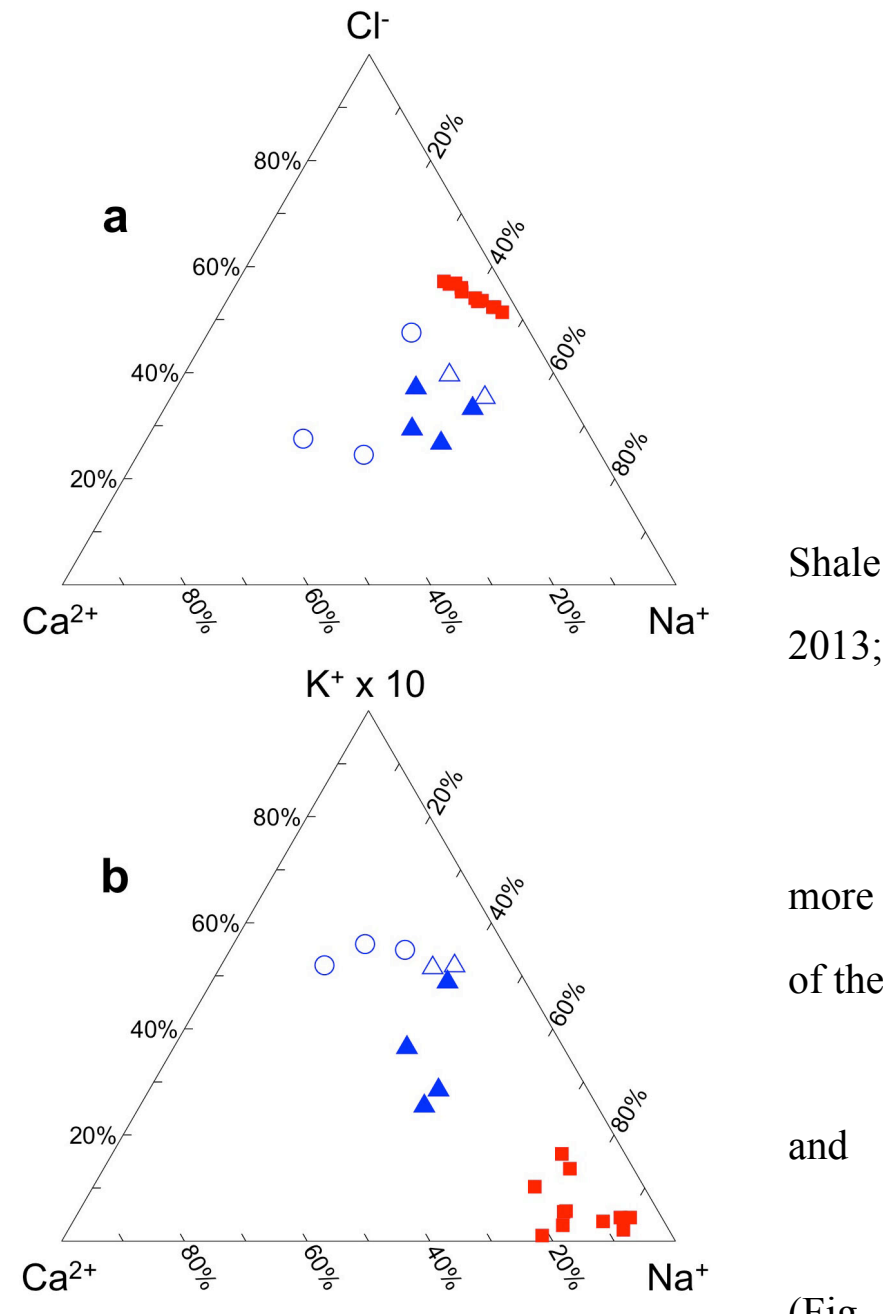

(Fig.

Figure 6. Ternary diagrams comparing molar concentrations with of $\mathrm{Ca} 2+, \mathrm{Na}+, \mathrm{K}+$ and $\mathrm{Cl}$ in water leachates from this study to those in Marcellus produced water (filled red squares) from Haluszczak et al. (2013). Marcellus Shale leachates are filled blue triangles, Hamilton Group leachates are open triangles, and open circles are overlying and underlying sandstones and limestones..

waters, possibly due to precipitation of barite (scaling) in rock fractures or the borehole, or to geographic variations in sulfate levels (Engle and Rowan, 2014). Even the $\mathrm{NH}_{4} \mathrm{Ac}$ (exchangeable cation) leachates, which contain $>60 \%$ of the extractable $\mathrm{Ba}$, do not reach $\mathrm{Ba} / \mathrm{Ca}$ ratios as high as the highest produced waters. On the whole, the offset in major cations and anions between Marcellus produced water and all leachates indicates that the dominant source of 
TDS in Marcellus Shale produced water is not from dissolution of soluble components of shale during hydraulic fracture stimulation. Nonetheless, longer-term leaching studies under the P-T-X conditions of hydraulic fracturing are needed to better replicate the downhole environment and to evaluate the resulting chemistry of fluid-shale interaction.

\subsection{Origin of high-TDS Marcellus Shale} produced water

If dissolution of water-soluble components of the shale cannot explain the chemistry of Marcellus produced waters, other possibilities include extraction of tightly bound pore water (Balashov et al., 2015) or migration of stratabound
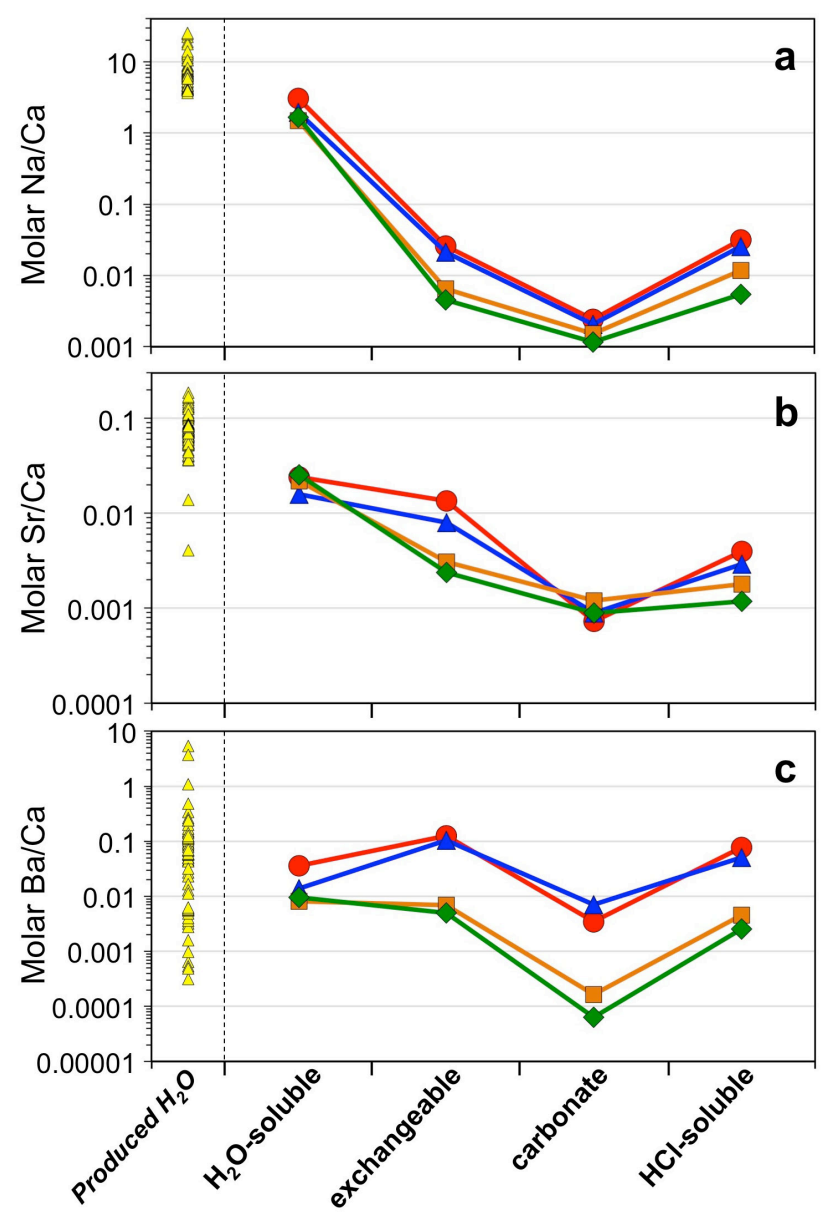

Figure 7. Molar ratios of $\mathrm{Na} / \mathrm{Ca}, \mathrm{Sr} / \mathrm{Ca}$ and $\mathrm{Ba} / \mathrm{Ca}$ of the Marcellus Shale sequential leachates. Data from Marcellus Shale produced water are shown for comparison (from Chapman et al., 2012; Haluszczak et al., 2013; Capo et al., 2014). Symbols are the same as in Figure 3.

formation waters due to hydraulic fracturing (Capo et al., 2014; Rowan et al., 2015). Nearly all of the sodium was stripped by the water extraction (Fig. 3a), so the total amount of Na extracted can be used to estimate the volume of pore-bound water in the Marcellus Shale samples, assuming that this leaching step would extract any available pore-bound water. Based on these leachate data, a rock:water ratio of about 50:1 (w/w) would be required to reach $\mathrm{Na}$ levels typical of late-stage Marcellus produced water. This is commensurate with the porosity range observed in the Marcellus Shale (Milliken et al., 2013), but it is unlikely that such a high rock:water interaction ratio could be achieved during hydraulic fracturing, because finely crushed drill 
cuttings likely expose a much greater surface area per unit mass than the hydraulic fracturing process. Given the probable high capillary pressures in the shale (Engelder, 2012), the net flow of water into the target formation during hydraulic fracturing (Vidic et al., 2013), and the differences in major element chemistry between the water leachates and Marcellus produced water (Section 4.1), we consider it unlikely that the observed volume of high-TDS waters (even during the low-flow production phase) represents solely pore-bound water that was immobile until being released by hydraulic fracturing.

We suggest that the high-TDS water produced during Marcellus Shale gas extraction represents long-lived, in situ formation water that is tapped or mobilized by hydraulic fracturing. This fluid could be present in pores, fractures and sandy lenses within the shale (Rowan et al., 2015), or in permeable units above or below the target zone. In this scenario, a portion of the injected fluid is removed during the flowback and early production phase of the well, with the remainder imbibed by the shale itself. During the main gas production phase, the relatively low pressure of the wellbore creates a hydraulic head gradient, inducing the formerly trapped fluids to flow along pathways created or intercepted by hydraulic fracturing. In the Marcellus Shale, the great depth to the producing region combined with the relative impermeability of the shale (even with fractures) generally minimizes the flow of in situ water to the wellbore. After cessation of hydraulic fracturing, the pressure differential is toward the wellbore itself; therefore, the primary vector for produced water to interact with shallower units or surface waters is likely to be via the wellbore, rather than upward migration along fractures (Soeder et al., 2014; Vengosh et al., 2014; Kolesar Kohl et al., 2014).

Limited Sr isotope data from water producing units below the Marcellus Shale (e.g., Medina Sandstone, Utica Shale) yield $\epsilon_{\mathrm{Sr}}^{\mathrm{SW}}$ values within the range of those of Marcellus produced waters (Osborn et al., 2012; Warner et al., 2012a), and the imprint of Marcellus-like waters in the $\mathrm{H}_{2} \mathrm{O}$ leachates extends up to the Tully Limestone (Fig. 5). However, highly saline produced water from Upper Devonian and Lower Mississippian units overlying the Tully Limestone (Dresel and Rose, 2010) typically have much more radiogenic $\epsilon_{\mathrm{Sr}}^{\mathrm{SW}}$ values (+98 to +169 ; Osborn et al., 2012; 
Chapman et al., 2012; 2013; Kolesar Kohl et al., 2014) than those from the Marcellus. This suggests that a long-lived hydrologic barrier exists between the Marcellus Shale and Upper Devonian gas-producing units, at least in portions of the Appalachian Basin. This barrier must have developed (or sealed) subsequent to hydrocarbon generation and expulsion, as Upper Devonian/Lower Mississippian gas- and oil-bearing units are thought to be sourced in part by the Marcellus Shale (Zagorski et al., 2012). In this scenario, tectonically driven basin-scale flow in the late Paleozoic (Garven et al., 1993; Evans and Battles, 1997; Osborn et al., 2012) served to homogenize the isotopic composition of fluids at or below the Tully Limestone, and in parts of the Appalachian Basin they have remained largely isolated from overlying units since that time. A barrier preventing upward movement of aqueous fluids could also serve to stop or slow gas migration, preserving the observed "reversals" of normal $\delta^{13} \mathrm{C}$ trends for methane, ethane and propane (Burruss and Laughrey, 2010) in Marcellus and deeper units. In the northeastern section of the Marcellus play closer to the Appalachian structural front, faulting and folding could have provided pathways for deeper fluids (aqueous and gas) to migrate upward and mix with the shallower formation waters, in some cases approaching the near surface environment (e.g., at Salt Springs State Park, Pennsylvania; Warner et al., 2012a; Johnson et al., 2015).

\subsection{Post-depositional fluid evolution}

For the samples processed in this study, each leaching solution extracted $\mathrm{Sr}$ with a distinct ${ }^{87} \mathrm{Sr} /{ }^{86} \mathrm{Sr}$ ratio, indicating cation reservoirs within individual samples that remained mutually isolated for possibly hundreds of millions of years. The lowest ${ }^{87} \mathrm{Sr} /{ }^{86} \mathrm{Sr}$ ratios were in the carbonate mineral fraction dissolved by acetic acid. Unaltered calcium carbonate that

precipitated from Middle Devonian seawater would have an $\epsilon_{\mathrm{Sr}}^{\mathrm{SW}}$ value in the range of -22 to -17 $\left({ }^{87} \mathrm{Sr} /{ }^{86} \mathrm{Sr}=0.7076-0.7079\right.$; Diener et al., 1996). The lowest value measured in the carbonate fraction of Marcellus Shale samples from this study was -12.9, which approaches the expected Devonian carbonate ratio (Fig. 5). To evaluate the possibility of introducing non-carbonate Sr to 


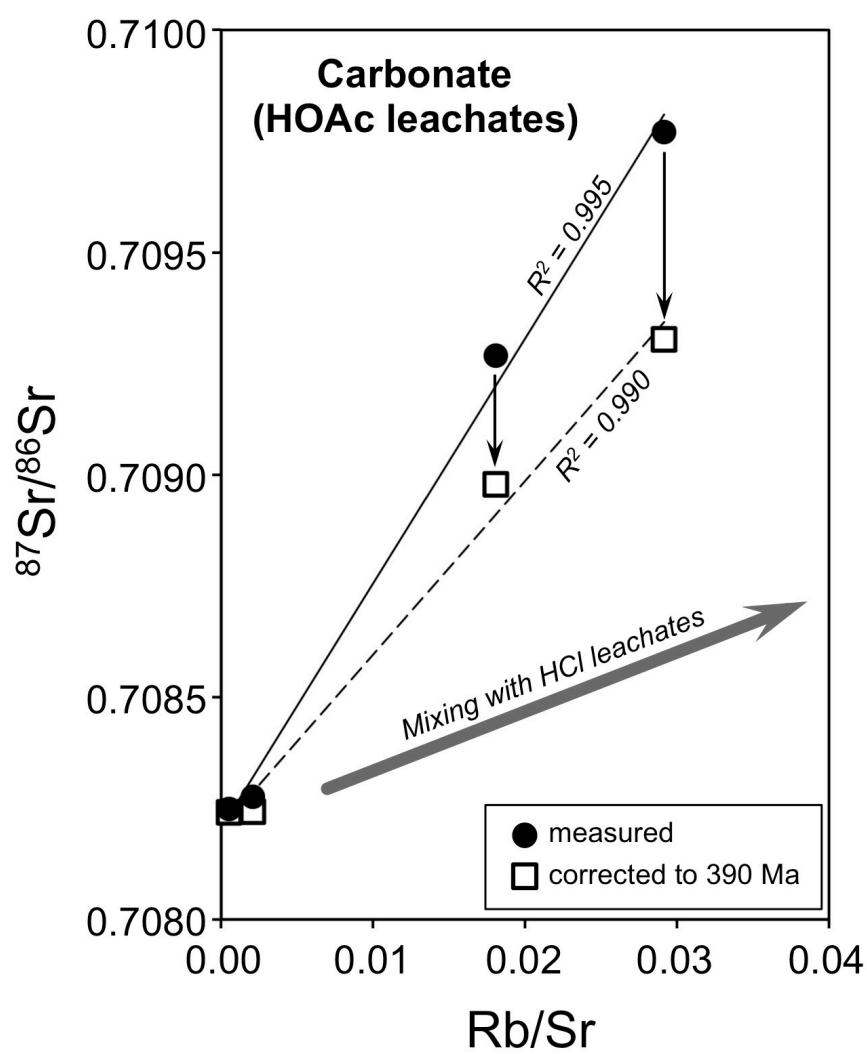

Figure 8. $\mathrm{Rb} / \mathrm{Sr}-{ }^{87} \mathrm{Sr} r{ }^{86} \mathrm{Sr}$ mixing diagram for the acetic acid leachates $(\approx$ carbonate). The linear trends suggest mixing between "pristine" carbonate and a high ${ }^{87} \mathrm{Sr} /{ }^{86} \mathrm{Sr}$ and $\mathrm{Rb} / \mathrm{Sr}$ endmember. Open squares are the values for the carbonate corrected back to the $\sim 390$ Ma age of deposition of the Marcellus Shale, which also display a high level of correlation (dashed line). The thick gray arrow shows the trajectory for mixing with the $\mathrm{HCl}$ leachate endmember; given that the carbonate does not follow this trajectory, the observed trend is unlikely to be a leaching artifact. carbonate Sr during the HOAc leaching process, we plot ${ }^{87} \mathrm{Sr} /{ }^{86} \mathrm{Sr}$ vs. $\mathrm{Rb} / \mathrm{Sr}$ for the HOAc leaches in Figure 8. The measured values have a strong linear correlation $\left(\mathrm{R}^{2}=\right.$ 0.995), suggesting mixing of a low ${ }^{87} \mathrm{Sr} /{ }^{86} \mathrm{Sr}$, low $\mathrm{Rb} / \mathrm{Sr}$ component with a component high in both. When the ${ }^{87} \mathrm{Sr} /{ }^{86} \mathrm{Sr}$ ratios are corrected for ${ }^{87} \mathrm{Rb}$ decay to the likely time of deposition ( $\sim 390 \mathrm{Ma})$, the values shift slightly downward, but the correlation remains. The apparent mixing relationship could reflect deposition of carbonate cement from an evolving diagenetic fluid receiving high $\mathrm{Rb}$, high $\epsilon_{\mathrm{Sr}}^{\mathrm{SW}}$ inputs. A portion of the trend could also represent a small input from the shale clastic component during leaching, which would have a relatively greater influence on the shale samples with low carbonate content. However, based on the component extracted with the stronger $\mathrm{HCl}$ leachate, leaching of more resilient $\mathrm{Rb}$ and $\mathrm{Sr}$ would move values toward a much higher $\mathrm{Rb} / \mathrm{Sr}$ endmember than is observed (gray arrow, Fig. 8). Moreover, the observation that the stratigraphically separated (by $\sim 50 \mathrm{~m}$ ) samples of Marcellus Shale fall along a welldefined trend implies a petrogenetic relationship rather than localized leaching artifacts.

If the carbonate cement in the shale represents an early diagenetic component, the exchangeable and water-soluble reservoirs reflect overprinting by later fluid flow processes. A possible geochemical fluid evolution pathway is demonstrated in Figure 9. The initial 


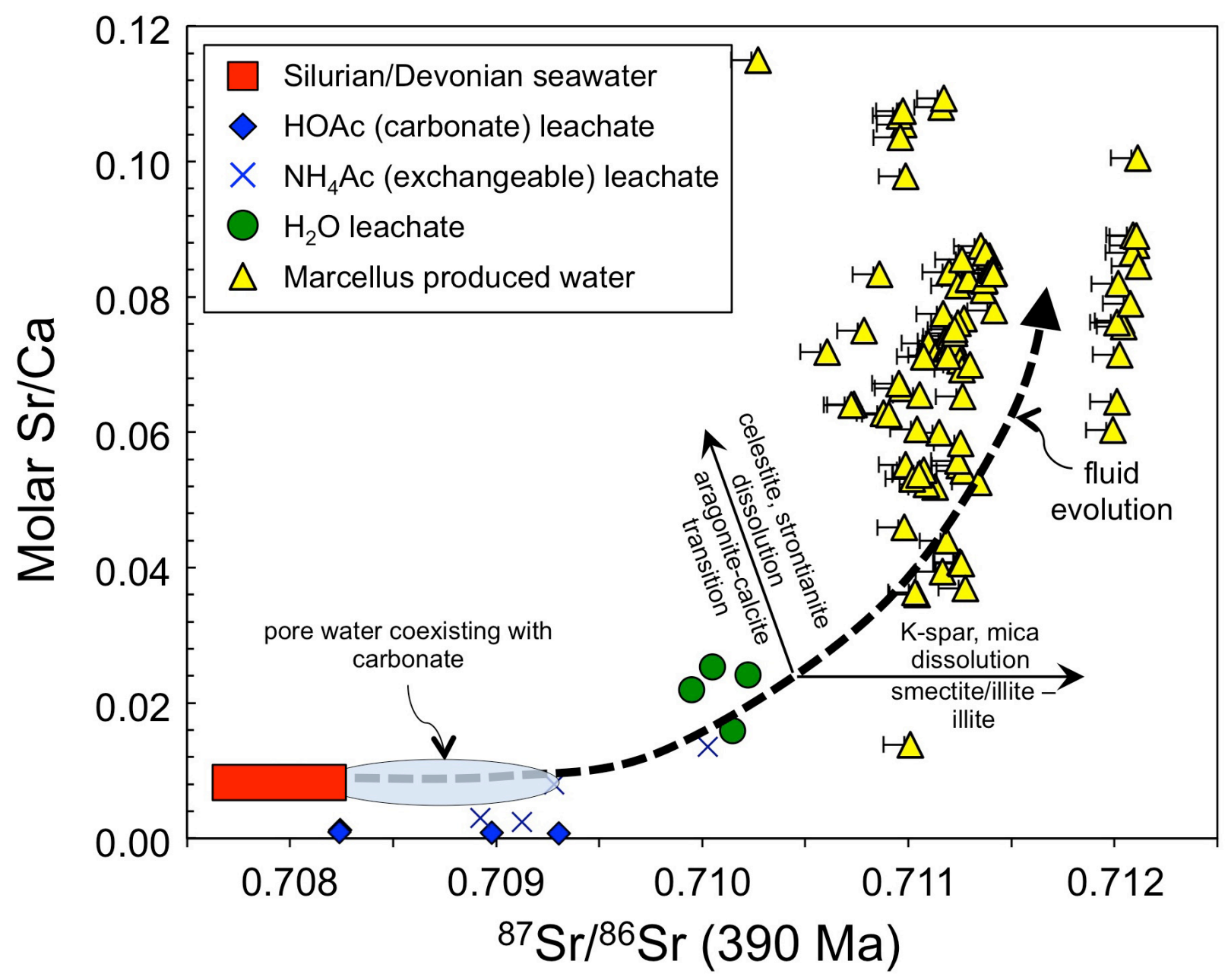

Figure 9. Leachate $\mathrm{Sr} / \mathrm{Ca}$ ratios and $87 \mathrm{Sr} / 86 \mathrm{Sr}$ values corrected for ${ }^{87} \mathrm{Rb}$ decay to $390 \mathrm{Ma}$. Also shown are published produced water data (yellow triangles) that are not corrected to $390 \mathrm{Ma}$ because Rb concentrations were not available; however, unpublished data indicate that Marcellus produced waters have very low $\mathrm{Rb} / \mathrm{Sr}$ ratios, leading to age corrections of $<0.0001$ (maximum correction of 0.0001 indicated with error bar). The dashed line indicates an inferred fluid evolution line for diagenetic/catagenetic fluids following deposition of the Marcellus Shale. The arrows indicate approximate vectors for aragonite recrystallization to calcite and dissolution of celestite/strontianite (movement toward high $\mathrm{Sr} / \mathrm{Ca}$ with seawater ${ }^{87} \mathrm{Sr} /{ }^{86} \mathrm{Sr}$ signatures), and for transformation of smectite-illite interlayered clays to illite and dissolution of K-feldspar and mica (movement toward higher ${ }^{87} \mathrm{Sr} /{ }^{86} \mathrm{Sr}$ with negligible effect on $\mathrm{Sr} / \mathrm{Ca}$ ). The light blue shaded region represents the calculated $\mathrm{Sr} / \mathrm{Ca}$ of pore fluid that would be in equilibrium with coexisting calcite cement (dark blue diamonds) extracted with HOAc. Note that the shale water leachates (filled green circles), when corrected to $390 \mathrm{Ma}$, fall almost entirely below the produced water values.

diagenetic/pore fluid after deposition would have had a Middle Devonian or older seawater ${ }^{87} \mathrm{Sr}{ }^{86} \mathrm{Sr}$ signature, as it likely consisted of evaporated paleo-seawater (Rowan et al., 2015). This fluid could have originated from within the Marcellus or from deeper evaporites sources (e.g., the Silurian Salina Group). Clay transformations within and below the Marcellus Shale from smectite-illite interlayers to primarily illite would expel radiogenic Sr into the pore fluid, moving 
the fluid to higher ${ }^{87} \mathrm{Sr} /{ }^{86} \mathrm{Sr}$ values (Chaudhuri and Clauer, 1993; Osborn et al., 2012), while minimally affecting the $\mathrm{Sr} / \mathrm{Ca}$ ratio of the fluid. In addition, dissolution of radiogenic minerals such as K-feldspar and mica could also drive the ${ }^{87} \mathrm{Sr} /{ }^{86} \mathrm{Sr}$ ratio upward; Chaudhuri and Clauer (1993) suggest that this is an important process for modifying the $\mathrm{Sr}$ isotope composition of oilfield produced waters. The $\mathrm{Sr} / \mathrm{Ca}$ ratio would increase as aragonite-calcite transformations released Sr into the diagenetic fluid (McGregor and Gagan, 2003). Strontium could also be contributed by dissolution of celestite (observed in the underlying Oriskany Sandstone; Stowe, 1928) or strontianite (observed in septarian concretions in the Marcellus Shale; Chamberlain et al., 1986; Siegel et al., 1987), although Siegel et al. (1987) suggest that the strontianite formed during the Pleistocene.

We suggest that a combination of these processes operated both below and within the Marcellus shale to move the diagenetic fluid along the pathway shown in Figure 9. Early-formed carbonate cement (with $\mathrm{Sr} / \mathrm{Ca}$ lower than its coexisting fluid) preserves the early fluid composition, while later fluid compositions were imprinted on the exchange sites (with variable $\mathrm{Sr} / \mathrm{Ca}$ depending on the sites) and finally trapped within pores in the shale when compaction restricted further fluid migration. This trapped component became the water-leachable portion (either as trapped fluid or salt residues from its evaporation after the cuttings were brought to the surface). The observation that leachates from sandstone and limestone samples adjacent to the Marcellus Shale have similar Sr isotope characteristics as the shale (Fig. 5) indicates that the isotopic signatures of these reservoirs were not imparted by the host rock. The highly saline produced water from Marcellus gas wells could represent a continuation of these processes (as indicated in Figure 9) or they could result from basin-scale fluid flow (primarily at or below the level of the Hamilton Group), with their final composition reflecting an amalgamation of all of these processes on a basin-wide scale. In either case, a portion of this fluid became trapped in fractures or permeable units within, below, and possibly above the Marcellus Shale, to be tapped by induced fractures. 


\section{Conclusions}

Dry-drilled cuttings extracted within, below and above the Marcellus Shale from a well in Tioga County, New York State, USA, were subjected to a sequential leaching procedure in order to determine geochemical reservoirs, element mobility, fluid flow history, and the origin of dissolved solids in Marcellus Shale produced water. Major findings include:

1. The four leaching solutions (water, ammonium acetate, acetic acid, and hydrochloric acid) extracted geochemically and isotopically distinct element suites from the shale and surrounding units. Of the total amount extracted, nearly all of the Ba was located in exchangeable sites, the $\mathrm{Na}$ was primarily water-soluble, and most of the $\mathrm{Ca}$ was in carbonate. Other elements exhibited more complex extraction patterns depending on the lithology. In all cases the ${ }^{87} \mathrm{Sr} /{ }^{86} \mathrm{Sr}$ of the leachate decreased progressively with sequential leaches of water, ammonium acetate, and acetic acid (carbonate), and increased in the $\mathrm{HCl}$ leachate.

2. Extracted water-soluble and exchangeable components of the Marcellus Shale yielded ${ }^{87} \mathrm{Sr} /{ }^{86} \mathrm{Sr}$ ratios generally within the range of Marcellus produced waters, but the major element geochemistry was not consistent with the derivation of produced water dissolved solids from water-rock interaction during hydraulic fracturing. Total dissolved solids in the 60:1 water:rock leachates were lower than those in produced water by a factor of at least $10^{3}$. High-TDS produced waters from the Marcellus Shale more likely represent formation waters in sandy lenses, fractures or adjacent units that are tapped by hydraulic fracturing.

3. The generally observed trend in hydraulic fracturing flowback water of rapidly climbing ${ }^{87} \mathrm{Sr} /{ }^{86} \mathrm{Sr}$ ratios over the first few days followed by stabilization or very slow increases in subsequent produced water can be explained by initial dissolution of shale carbonate and well casing cement followed by gradual mixing in of high-TDS formation waters.

4. Marcellus Shale produced waters, water leachates from the Middle Devonian samples in this study, and the few deeper brines that have been analyzed for Sr isotopes all exhibit similar ${ }^{87} \mathrm{Sr} /{ }^{86} \mathrm{Sr}$ ratios. In contrast, the ${ }^{87} \mathrm{Sr} /{ }^{86} \mathrm{Sr}$ ratios of overlying Upper Devonian/Lower 
Mississippian produced waters in many parts of the Appalachian Basin are significantly higher, suggesting that Middle Devonian and older produced waters were prevented from migrating upward into overlying units over much of their history.

5. Geochemically and isotopically distinct reservoirs record different stages of fluid evolution of the Marcellus Shale. Carbonate cement appears to reflect precipitation from an early fluid with near-seawater ${ }^{87} \mathrm{Sr} /{ }^{86} \mathrm{Sr}$ ratios, while later overprints on exchange sites and ultimately pore water indicate a more radiogenic fluid, possibly due to expulsion of Sr from clays during smectite-illite transformation or K-spar and mica dissolution within and below the Marcellus Shale.

\section{Acknowledgements}

We thank M. Engle and E. Rowan for detailed and insightful reviews that greatly improved the manuscript. This work was supported by the Colcom Foundation (CSK, RCC, JRG), with additional funding from the U.S. Department of Energy, Office of Fossil Energy, as performed through the National Energy Technology Laboratory's ongoing research under the RES contract DE-FE0004000 (RCC, BWS). 


\section{References}

Akob, D.M., Cozzarelli, I.M., Dunlap, D.S., Rowan, E.L., Lorah, M.M., 2015. Organic and inorganic composition and microbiology of produced waters from Pennsylvania shale gas Wells. Appl. Geochem. this volume.

Andersson, P.S., Wasserburg, G.J., Ingri, J., Stordal, M.C., 1994. Strontium, dissolved and particulate loads in fresh and brackish waters: the Baltic Sea and Mississippi Delta. Earth Planet. Sci. Lett. 124, 195-210.

Balashov, V.N., Engelder, T., Gu, X., Fantle, M.S., Brantley, S.L., 2015. A model describing flowback chemistry changes with time after Marcellus Shale hydraulic fracturing. Am. Assoc. Petroleum Geol. Bull. DOI:10.1306/06041413119.

Barbot, E., Vidic, N.S., Gregory, K.B., Vidic, R.D., 2013. Spatial and temporal correlation of water quality parameters of produced waters from Devonian-age shale following hydraulic fracturing. Environ. Sci. Technol. 47, 2562-2569.

Basan, P.B., Kissling, D.L., Hemsley, K.D., Kersey, D.G., Dow, W.G., Chaiffetz, M.S., Isaacson, P., Barrett, S., Carne, L., 1980. Geological Study and Reservoir Evaluation of Early Devonian Formations of the Appalachians, Robertson Research Inc., Houston, TX.

Beaumont, C., Quinlan, G., Hamilton, J., 1988. Orogeny and stratigraphy: Numerical models of the Paleozoic in the eastern interior of North America. Tectonics 7, 389-416.

Blauch, M.E., Myers, R.R., Moore, T.R., Lipinski, B.A., 2009. Marcellus Shale post-frac flowback waters - Where is all the salt coming from and what are the implications? Society of Petroleum Engineers Eastern Regional Meeting, Charleston, WV, pp. SPE 125740, pp. 1-20.

Brett, C.E., Baird, G.C., 1996. Middle Devonian sedimentary cycles and sequences in the northern Appalachian Basin. In: Witzke, B.J., Ludvigson, G.A., Day, J. (Eds.), Paleozoic Sequence Stratigraphy; Views from the North American Craton, GSA Special Papers, v. 306. Geological Society of America, Boulder, CO, pp. 213-241.

Burruss, R.C., Laughrey, C.D., 2010. Carbon and hydrogen isotopic reversals in deep basin gas: Evidence for limits to the stability of hydrocarbons. Org. Geochem. 41, 1285-1294. 
Capo, R.C., Stewart, B.W., Rowan, E.L., Kolesar, C.A., Wall, A.J., Chapman, E.C., Hammack, R.W., Schroeder, K.T., 2014. The strontium isotopic evolution of Marcellus Formation produced waters, southwestern Pennsylvania. Int. J. Coal Geol. 126, 57-63.

Carter, K.M., 2007. Subsurface rock correlation diagram, oil and gas producing regions of Pennsylvania. Pennsylvania Geological Survey Open-File Report OFOG 07-01.1, 4th ser., http://www.dcnr.state.pa.us/topogeo/publications/pgspub/openfile/drc/index.htm.

Chamberlain, S.C., Dossert, W.P., Siegel, D.I., 1986. A new paragenesis and new localities for witherite. Canadian Mineralogist 24, 79-90.

Chapman, E.C., Capo, R.C., Stewart, B.W., Hedin, R.S., Weaver, T.J., Edenborn, H.M., 2013. Strontium isotope quantification of siderite, brine, and acid mine drainage contributions to abandoned gas well discharges in the Appalachian Plateau. Appl. Geochem. 31, 109118.

Chapman, E.C., Capo, R.C., Stewart, B.W., Kirby, C.S., Hammack, R.W., Schroeder, K.T., Edenborn, H.M., 2012. Geochemical and strontium isotope characterization of produced waters from Marcellus Shale natural gas extraction. Environ. Sci. Technol. 46, 35453553.

Chaudhuri, S., Clauer, N., 1993. Stontium isotopic compositions and potassium and rubidium contents of formation waters in sedimentary basins: Clues to the origin of the solutes. Geochim. Cosmochim. Acta 57, 429-437.

DePaolo, D.J., Kyte, F.T., Marshall, B.D., O'Neill, J.R., Smit, J., 1983. Rb-Sr, Sm-Nd, K-Ca, O, and $\mathrm{H}$ isotopic study of Cretaceous-Tertiary boundary sediments, Caravaca, Spain: Evidence for an oceanic impact site. Earth Planet. Sci. Lett. 64, 356-373.

Diener, A., Ebneth, S., Veizer, J., Buhl, D., 1996. Strontium isotope stratigraphy of the Middle Devonian: Brachiopods and conodonts. Geochim. Cosmochim. Acta 60, 639-652.

Dresel, P.E., Rose, A.W., 2010. Chemistry and Origin of Oil and Gas Well Brines in Western Pennsylvania. Open-File Report OFOG, v. 10-01.0, Pennsylvania Geological Survey, Harrisburg, PA.

Engelder, T., 2012. Capillary tension and imbibition sequester frack fluid in Marcellus gas shale. Proc. Nat. Acad. Sci. 109, E3625. 
Engelder, T., Cathles, L.M., Bryndzia, L.T., 2014. The fate of residual treatment water in gas shale. J. Unconven. Oil Gas Resour. 7, 33-48.

Engle, M.A., Rowan, E.L., 2014. Geochemical evolution of produced waters from hydraulic fracturing of the Marcellus Shale, northern Appalachian Basin: A multivariate compositional data analysis approach. Int. J. Coal Geol. 126, 45-56.

Ettensohn, F.R., 1985. Controls on development of Catskill delta complex basis facies. In: Woodrow, D.W., Sevon, W.D. (Eds.), The Catskill Delta, Geological Society of America Special Paper 201, pp. 65-77.

Ettensohn, F.R., 1992. Controls on the origin of the Devonian-Mississippian oil and gas shales, east-central United States. Fuel 71, 1487-1492.

Ettensohn, F.R., 2004. Modeling the nature and development of major paleozoic clastic wedges in the Appalachian Basin, USA. J. Geodynam. 37, 657-681.

Evans, M.A., Battles, D.A., 1997. Regional syn-orogenic fluid migration in the central Appalachians: Fluid geochemistry and fluid migration pathways. In: Hendry, J.P., Carey, P.F., Parnell, J., Ruffell, A.H., Worden, R.H. (Eds.), Contributions to the Second International Conference on Fluid Evolution, Migration and Interaction in Sedimentary Basins and Orogenic Belts, pp. 87-92.

FracFocus, 2014. Hydraulic Fracturing: The Process. http://fracfocus.org/hydraulic-fracturinghow-it-works/hydraulic-fracturing-process

Garven, G., Ge, S., Person, M.A., Sverjensky, D.A., 1993. Genesis of stratabound ore deposits in the Midcontinent basins of North America. 1. The role of regional groundwater flow. Am. J. Sci. 293, 487-568.

Ground Water Protection Council and ALL Consulting, 2009. Modern Shale Gas Development in the United States: A Primer, Oklahoma City, OK, http://www.netl.doe.gov/technologies/oilgas/publications/epreports/shale_gas_primer_2009.pdf.

Haluszczak, L.O., Rose, A.W., Kump, L.R., 2013. Geochemical evaluation of flowback brine from Marcellus gas wells in Pennsylvania, USA. Appl. Geochem. 28, 55-61.

Harper, J.A., 2008. The Marcellus Shale_An old "new" gas reservoir in Pennsylvania. Penn. Geol. 38, 2-13. 
Hayes, T., 2009. Sampling and Analysis of Water Streams Associated with the Development of Marcellus Shale Gas. Report by the Gas Technology Institute, Des Plaines, IL. Marcellus Shale Coalition.

Johnson, J.D., Graney, J.R., 2015. Fingerprinting Marcellus Shale waste products from Pb isotope and trace metal perspectives. Appl. Geochem. this issue.

Johnson, J.D., Graney, J.R., Capo, R.C., Stewart, B.W., 2015. Identification and quantification of regional brine and road salt sources in watersheds along the New York / Pennsylvania border, USA. Appl. Geochem. this issue.

King, G.E., 2012. Hydraulic Fracturing 101: What every representative, environmentalist, regulator, reporter, investor, university researcher, neighbor and engineer should know about estimating frac risk and improving frac performance in unconventional oil and gas wells. SPE Hydraulic Fracturing Conference, The Woodland, Texas, USA, SPE-152596MS, pp. 1-80.

Kohl, D., Slingerland, R., Arthur, M., Bract, R., Engelder, T., 2014. Sequence stratigraphy and depositional environments of the Shamokin (Union Springs) Member, Marcellus Formation, and associated strata in the middle Appalachian Basin. Am. Assoc. Petroleum Geol. Bull. 98, 483-513.

Köhler, S.J., Dufaud, F., Oelkers, E.H., 2003. An experimental study of illite dissolution kinetics as a function of $\mathrm{pH}$ from 1.4 to 12.4 and temperature from 5 to $50^{\circ} \mathrm{C}$. Geochim. Cosmochim. Acta 67, 3583-3594.

Kolesar Kohl, C.A., Capo, R.C., Stewart, B.W., Wall, A.J., Schroeder, K.T., Hammack, R.W., Guthrie, G.D., 2014. Strontium isotopes test long-term zonal isolation of injected and Marcellus Formation water after hydraulic fracturing. Environ. Sci. Technol. 48, 98679873.

Kostelnik, J., Carter, K.M., 2012. Unraveling the stratigraphy of the Oriskany Sandstone: A necessity in assessing its site-specific carbon sequestration potential. Environ. Geosci. 16, 187-200.

Krauskopf, K.B., 1956. Dissolution and precipitation of silica at low temperatures. Geochim. Cosmochim. Acta 10, 1-26. 
Maloney, K.O., Yoxtheimer, D.A., 2013. Production and disposal of waste materials from gas and oil extraction from the Marcellus Shale play in Pennsylvania. Environ. Pract. 14, 278-287.

McGregor, H.V., Gagan, M.K., 2003. Diagenesis and geochemistry of Porites corals from Papua New Guinea: Implications for paleoclimate reconstruction. Geochim. Cosmochim. Acta $67,2147-2156$.

Milici, R.C., Swezey, C.S., 2006. Assessment of Appalachian Basin oil and gas resources: Devonian shale-Middle and Upper Paleozoic total petroleum system. U.S.G.S. Open-File Report 2006-1237, 1-70.

Milliken, K.L., Rudnicki, M., Awwiller, D.N., Zhang, T., 2013. Organic matter-hosted pore system, Marcellus Formation (Devonian), Pennsylvania. Am. Assoc. Petroleum Geol. Bull. 97, 177-200.

Osborn, S.G., McIntosh, J.C., Hanor, J.S., Biddulph, D., 2012. Iodine-129, ${ }^{87} \mathrm{Sr} /{ }^{86} \mathrm{Sr}$, and trace elemental geochemistry of northern Appalachian Basin brines: Evidence for basinalscale fluid migration and clay mineral diagenesis. Am. J. Sci. 312, 263-287.

Paytan, A., Kastner, M., Martin, E.E., Macdougall, J.D., Herbert, T., 1993. Marine barite as a monitor of seawater strontium isotope composition. Nature 366, 445-449.

Quinlan, G.M., Beaumont, C., 1984. Appalachian thrusting, lithospheric flexure, and the Paleozoic stratigraphy of the Eastern Interior of North America. Can. J. Earth Sci. 21, 973-996.

Rowan, E.L., Engle, M.A., Kirby, C.S., Kraemer, T.F., 2011. Radium content of oil- and gasfield produced waters in the northern Appalachian Basin (USA): Summary and discussion of data. U.S. Geol. Surv. Sci. Invest. Rep. 2011-5135, 1-31.

Rowan, E.L., Engle, M.A., Kraemer, T.F., Schroeder, K.T., Hammack, R.W., Doughten, M.W., 2015. Geochemical and isotopic evolution of water produced from Middle Devonian Marcellus Shale gas wells, Appalachian Basin, Pennsylvania. Am. Assoc. Petroleum Geol. Bull. DOI:10.1306/07071413146.

Rozalén, M.L., Huertas, F.J., Brady, P.V., Cama, J., García-Palma, S., Linares, J., 2008. Experimental study of the effect of $\mathrm{pH}$ on the kinetics of montmorillonite dissolution at $25^{\circ} \mathrm{C}$. Geochim. Cosmochim. Acta 72, 4224-4253. 
Schieber, J., 1996. Early diagenetic silica deposition in algal cysts and spores: a source of sand in black shales? J. Sed. Res. 66, 175-183.

Siegel, D.I., Chamberlain, S.C., Dossert, W.P., 1987. The isotopic and chemical evolution of mineralization in septarian concretions: Evidence for episodic paleohydrogeologic methanogenesis. Geol. Soc. Am. Bull. 99, 385-394.

Soeder, D.J., Sharma, S., Pekney, N., Hopkinson, L., Dilmore, R., Kutchko, B., Stewart, B., Carter, C., Hakala, A., Capo, R., 2014. An approach for assessing engineering risk from shale gas wells in the United States. Int. J. Coal Geol. 126, 4-19.

Spivak-Birndorf, L., Stewart, B.W., Capo, R.C., Chapman, E.C., Schroeder, K.T., Brubaker, T.M., 2012. Strontium isotope study of coal utilization by-products interacting with environmental waters. J. Environ. Qual. 41, 144-154.

Stewart, B.W., Capo, R.C., Chadwick, O.A., 2001. Effects of rainfall on weathering rate, base cation provenance, and $\mathrm{Sr}$ isotope composition of Hawaiian soils. Geochim. Cosmochim. Acta 65, 1087-1099.

Stowe, M.H., 1928. An occurrence of Oriskany sandstone with celestite cement. Am. J. Sci. 16, 446-450.

Vengosh, A., Jackson, R.B., Warner, N.R., Darrah, T.H., Kondash, A., 2014. A critical review of the risks to water resources from unconventional shale gas development and hydraulic fracturing in the United States. Environ. Sci. Technol. 48, 8334-8348.

Vidic, R.D., Brantley, S.L., Vandenbossche, J.M., Yoxtheimer, D., Abad, J.D., 2013. Impact of shale gas devleopment on regional water quality. Science 340.

Warner, N.R., Jackson, R.B., Darrah, T.H., Osborn, S.G., Down, A., Zhao, K., White, A., Vengosh, A., 2012a. Geochemical evidence for possible natural migration of Marcellus Formation brine to shallow aquifers in Pennsylvania. Proc. Nat. Acad. Sci. 109, 1196111966.

Warner, N.R., Jackson, R.B., Darrah, T.H., Osborn, S.G., Down, A., Zhao, K., White, A., Vengosh, A., 2012b. Reply to Engelder: Potential for fluid migration from the Marcellus Formation remains possible. Proc. Nat. Acad. Sci. 109, E3626.

Zagorski, W.A., Wrightstone, G.R., Bowman, D.C., 2012. The Appalachian Basin Marcellus gas play: Its history of development, geologic controls on production, and future potential as 
a world-class reservoir. In: Breyer, J.A. (Ed.), Shale Reservoirs - Giant Resources for the 21st Century, AAPG Memoir, v. 97, pp. 172-200. 